\title{
GROWTH AND YIELD PERFORMANCE OF FOXTAIL MILLETS UNDER SALINITY
}

\author{
A. Nahar ${ }^{1,}$, M. A. Mannan', M. A. A. Mamun ${ }^{1}$ and T. K. Ghosh ${ }^{2}$ \\ ${ }^{1}$ Department of Agronomy and ${ }^{2}$ Department of Crop Botany \\ Bangabandhu Sheikh Mujibur Rahman Agricultural University, Gazipur-1706. \\ ${ }^{*}$ Corresponding author, E-mail: nisu2919@gmail.com
}

(Received: 7 December 2017, Accepted: 22 February 2018)

Keywords: Coastal area, minor cereal, salt tolerance, stress, yields.

\begin{abstract}
Crop diversification in saline affected coastal areas is crucial for food security in Bangladesh. A pot experiment was conducted at polythene house at Bangabandhu Sheikh Mujibur Rahman Agricultural University, Gazipur-1706 during May to August, 2017 to determine the effect of salt stress on growth and yield performance of foxtail millets. Five foxtail millets genotypes viz. (i) BARI Kaon-1 (check), (ii) BD-878, (iii) BD-897, (iv) BD-891 and (v) BD-881 were tested under three salt stresses viz. (i) control ( $0 \mathrm{dS} / \mathrm{m}$ ), (ii) $6 \mathrm{dS} / \mathrm{m}$ and (iii) $12 \mathrm{dS} / \mathrm{m}$. Completely randomized design (CRD) with three replications was followed in the study. The growth parameter viz. stem dry matter, leaf dry matter and root dry matter production of foxtail millets genotypes were significantly varied due to salinity stresses. Salinity stresses also significantly influenced yield and yield contributing characteristics of foxtail millets. The genotypes BD-897 and BD-881 produced the higher dry matter, grains per panicle and grain yield per plants under the saline level of $6 \mathrm{dS} / \mathrm{m}$. The higher stress tolerance index of both the genotypes demonstrate that the genotypes BD-897 and BD-881 were more salt tolerant.
\end{abstract}

\section{Introduction}

Foxtail millet (Setaria italica L.) is one of the world's most important ancient crops with its domestication in China dating back to 8700 years (Liu et al., 2009). It is widely cultivated in Asia, Europe, North America, Australia and North Africa for grain or forage (Austin, 2006). Foxtail millet has attracted international research attention due to its high salinity stress tolerance, low incidence of pest and diseases, high photosynthetic efficiency and nutritional values (Liu et al., 2011; Vetriventhan et al., 2012). Global estimates, dating back two decades, indicate a constant increase in salt affected soils. It has been estimated that worldwide the cultivated area affected by about $23 \%$ by salinity and $37 \%$ by sodicity (Tanji et al., 1990). About $53 \%$ of the coastal areas are affected by salinity in Bangladesh. It was found that about $10 \%$ yield was decreased if the crop was wetted with water of electrical conductivity $1.70 \mathrm{dS} / \mathrm{m}$ (Evans, 2006). It has become imperative to explore the possibilities of increasing potential of saline affected area for increased production of crops.

Also, the usual course of salinity increase in intensely irrigated cropping systems and the transient dry land salinity threatens crop production; necessitating identification of both crop species that can tolerate the soil salinity the best and an understanding of the genetic variation within each species for tolerance to saline conditions. Foxtail millet (Setaria italic L. Beauv) is a Panicoideae grass that has been reported to have comparable tolerant level to drought (Doust et al., 2009) and salinity (Kafi et al., 2009), thus it became an important food crop in the arid and semi-arid regions. Foxtail millet can be a potential crop for salt affected soils due to its high 
level of tolerance to salinity (Maas, 1985) and the salt 'escape' potential due to its short growing duration. There are many sporadic experiments conducted to assess the salinity tolerance of foxtail millets, however, more systematic studies are needed to generate information to improve the productivity of the crops under marginal environment in Bangladesh. Considering the above facts, this experiment was designed to evaluate the effect of salt stress on growth and yield performance of foxtail millets.

\section{Materials and methods}

A pot experiment was conducted at the Agronomy Research Field of Bangbandhu Sheikh Mujibur Rahman Agricultural University, Gazipur-1706 from May to August 2017. The site is located under Agro Ecological Zone- 28. Five foxtail millets genotypes viz. (i) BARI Kaon-1 (check), (ii) BD-878, (iii) BD-897, (iv) BD-891 and (v) BD-881 were tested under three salt stress viz. (i) control (0 dS/m), (ii) $6 \mathrm{dS} / \mathrm{m}$ and (iii) $12 \mathrm{dS} / \mathrm{m}$. The experiment was laid out in a complete randomized design with three replications. The pots used for the experiment having 30 $\mathrm{cm}$ length and $24 \mathrm{~cm}$ diameter. The pots were filled with soil and cowdung with 2:1 ratio. Nitrogen, triple super phosphate, murate of potash and gypsum were applied at the rate of 7028-50-11 kg ha-1 N-P-K-S, respectively (FRG, 2012). Ten seeds of foxtail millet per pot were sown on 15 January 2017 and the seeds were germinated within 20 January 2017. Salt solution was applied at three days interval starting from 15 days after sowing (DAS) and continued up to 64 DAS. The crops were harvested at full maturity selecting three plants per pot. Data was collected on leaf dry matter, stem dry matter, root dry matter production, grain weight, panicle weight and length and grain yield per plant ${ }^{-1}$. To record dry matter the partitioned plant parts were dried in an oven at $70^{\circ} \mathrm{C}$ for 5 days. Three plants per pot were harvested at maturity and threshing, cleaning and drying of grain were done separately pot by pot. Grain was cleaned and sun dried. Stress tolerance index (STI) was calculated using following equation suggested by (Fernandez, 1992).

$$
\mathrm{STI}=\quad \frac{\mathrm{Ys} \times \mathrm{Yp}}{\overline{\mathrm{Y}} \mathrm{p}^{2}}
$$

Where, $\mathrm{Ys}=$ yield in stress condition, $\mathrm{Yp}=$ yield in control (non-stress) condition and $\overline{\mathrm{Y}} \mathrm{p}^{2}=$ mean yield in control condition. Data were analyzed using ANOVA to evaluate treatment effects and the means were separated following least significant difference (LSD) at 5\% level of probability (Gomez and Gomez, 1984).

\section{Results and discussion}

\section{Dry matter production}

Leaf dry matter, root dry matter and stem dry matter of foxtail millet significantly influenced due to interaction of salinity $\times$ genotypes. Dry matter accumulation in leaf, root and stem reduced gradually with the increasing of saline concentration. However, the magnitude of reduction is different in different genotypes. Genotypes BD-897, BD-891 and BD-881 produced higher amount of leaf root and stem dry matter irrespective of salinity level (Table 1). Total dry matter production of foxtail millet varied significantly due to interaction of salinity $\times$ genotypes. However, the reduction of dry matter was higher in case of salt sensitive var. BARI Kaon-1 compared to genotype BD-897 and BD-881 (Fig. 1). Zheng et al. (2008) reported that the chlorophyll content of plant leaf reduced significantly under saline condition. Chlorophyll is the most important photosynthetic pigment. Due to lacks of this pigment, the production and accumulation of dry matter in leaf, stem and root is hampered in plants. Different authors (Hasan et al., 2015; Khan et al., 2009; Ashraf et al., 2005) stated that salinity decreased chlorophyll content of leaf. 
Table 1. Dry matter production of foxtail millet genotypes under saline condition

\begin{tabular}{|c|c|c|c|c|c|c|c|c|c|}
\hline \multirow{2}{*}{ Genotypes } & \multicolumn{3}{|c|}{$\begin{array}{l}\text { Leaf dry matter } \\
\left(\mathrm{g}_{\text {plant }}^{-1}\right)\end{array}$} & \multicolumn{3}{|c|}{$\begin{array}{l}\text { Root dry matter } \\
\left(\mathrm{g}_{\text {plant }}^{-1}\right)\end{array}$} & \multicolumn{3}{|c|}{$\begin{array}{l}\text { Stem dry matter } \\
\left(\text { g plant }^{-1}\right)\end{array}$} \\
\hline & Control & $\begin{array}{c}6 \\
\mathrm{dS} / \mathrm{m}\end{array}$ & $12 \mathrm{dS} / \mathrm{m}$ & Control & $\begin{array}{c}6 \\
\mathrm{dS} / \mathrm{m}\end{array}$ & $\begin{array}{c}12 \\
\mathrm{dS} / \mathrm{m}\end{array}$ & Control & $\begin{array}{c}6 \\
\mathrm{dS} / \mathrm{m}\end{array}$ & $\begin{array}{c}12 \\
\mathrm{dS} / \mathrm{m}\end{array}$ \\
\hline BARI Kaon-1 & 2.30 & 2.23 & 1.81 & 0.89 & 0.55 & 0.59 & 3.11 & 1.75 & 1.98 \\
\hline BD-878 & 1.93 & 2.38 & 1.82 & 1.50 & 0.90 & 0.68 & 6.23 & 3.87 & 2.85 \\
\hline BD-897 & 2.46 & 2.76 & 2.47 & 1.44 & 1.41 & 1.01 & 6.48 & 4.90 & 3.20 \\
\hline BD-891 & 2.94 & 2.27 & 2.20 & 1.65 & 0.82 & 0.77 & 5.94 & 3.60 & 3.57 \\
\hline BD-881 & 2.10 & 2.12 & 2.29 & 1.20 & 1.01 & 1.07 & 6.53 & 4.94 & 3.60 \\
\hline \multicolumn{10}{|l|}{$\begin{array}{l}\text { LSD }_{0.05} \\
\end{array}$} \\
\hline Salinity ( & & NS & & & 0.29 & & & 0.91 & \\
\hline Genotype (G) & & NS & & & 0.37 & & & 1.16 & \\
\hline $\mathrm{S} \times \mathrm{G}$ & & 0.79 & & & 0.65 & & & 2.02 & \\
\hline $\mathrm{CV}(\%)$ & & 21 & & & 37.7 & & & 29.1 & \\
\hline
\end{tabular}

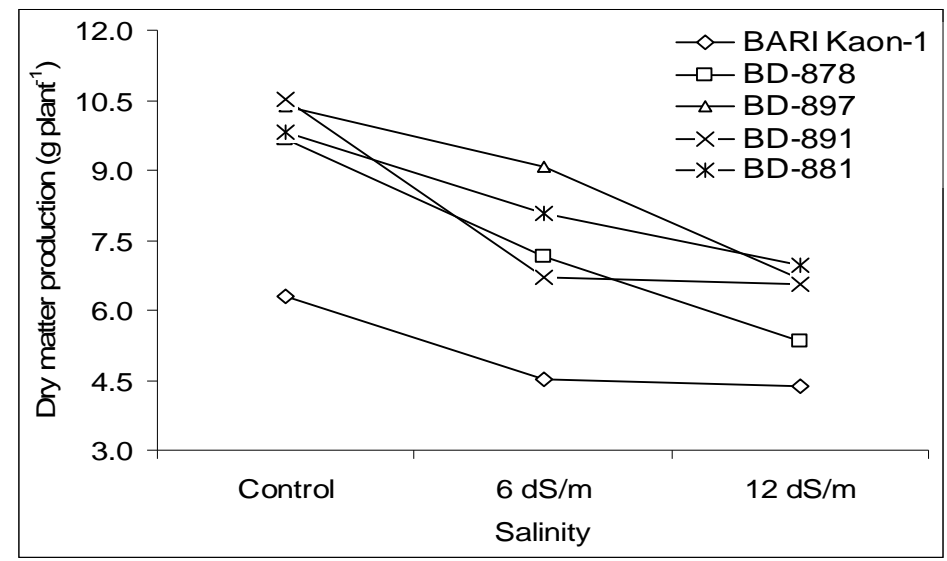

Fig. 1. Effect of salinity on total dry matter production of foxtail millet genotypes

\section{Grain yield}

The interaction effect of salinity $\times$ genotypes demonstrated a significant effect on panicle length and panicle weight of foxtail millet (Table 2). Likewise dry matter production, the panicle length and weight also decreased with the increases of salinity level in all genotypes. The panicle length of BARI Kaon-1 reduced by 1.7 and $5.68 \mathrm{~cm}$ in 6 and $12 \mathrm{dS} / \mathrm{m}$, respectively compared to control. However, BD-897 and BD-881 produced panicles of 13.77 and $14.89 \mathrm{~cm}$ length in control while 13.11 and $13.78 \mathrm{~cm}$ in $6 \mathrm{dS} / \mathrm{m}$; and 11.78 and $13.10 \mathrm{~cm}$ in $12 \mathrm{dS} / \mathrm{m}$, respectively. Similarly, panicle weight of BARI Kaon-1 was $1.70 \mathrm{~g}$ in control while it was 0.90 and $0.40 \mathrm{~g}$ in 6 and $12 \mathrm{dS} / \mathrm{m}$, respectively. On the other hand, BD-897 and BD-881 gave panicles of $1.33 \mathrm{~g}$ weight in control whereas it was 1.39 and 1.02 in $6 \mathrm{dS} / \mathrm{m}$; and 1.00 and $0.84 \mathrm{~g}$ in $12 \mathrm{dS} / \mathrm{m}$, respectively (Table 2 ). The interaction of salinity $\times$ genotypes exerted a significant effect on grain yield of foxtail millets.

Table 2. Panicle length and weight of foxtail millets genotypes under saline condition

\begin{tabular}{lcccccc}
\hline \multirow{2}{*}{ Genotypes } & \multicolumn{3}{c}{ Panicle length $(\mathrm{cm})$} & \multicolumn{3}{c}{ Panicle weight $\left(\right.$ g panicle $\left.^{-1}\right)$} \\
\cline { 2 - 7 } & Control & $6 \mathrm{dS} / \mathrm{m}$ & $12 \mathrm{dS} / \mathrm{m}$ & Control & $6 \mathrm{dS} / \mathrm{m}$ & $12 \mathrm{dS} / \mathrm{m}$ \\
\hline BARI Kaon-1 & 15.01 & 13.31 & 9.33 & 1.70 & 0.90 & 0.40 \\
BD-878 & 15.97 & 11.92 & 11.72 & 1.26 & 0.88 & 0.60 \\
\hline
\end{tabular}




\begin{tabular}{lcccccc}
\hline BD-897 & 13.77 & 13.11 & 11.78 & 1.33 & 1.39 & 1.00 \\
BD-891 & 13.74 & 12.71 & 10.33 & 1.33 & 1.23 & 0.63 \\
BD-881 & 14.89 & 13.78 & 13.10 & 1.17 & 1.02 & 0.84 \\
\hline LSD 0.05 & & & & & & \\
Salinity (S) & & 1.66 & & & 0.21 & \\
Genotype (G) & & NS & & & NS & \\
S $\times$ G & & 3.72 & & & 0.47 & \\
CV $(\%)$ & & 27.1 & & & 27.2 & \\
\hline
\end{tabular}



Fig. 2. Effect of salinity on grain yield of foxtail millet genotypes

The grain yield reduced with the increases of salinity level, but the magnitudes of yield reduction was not same for all foxtail millet genotypes. BARI Kaon-1 produced the highest yield in control, but lowest under stress condition. BD-897 gave the second highest yield in control but top yielder under both 6 and $12 \mathrm{dS} / \mathrm{m}$ salinity (Fig. 2). Similarly, foxtail millet genotype BD-881 gave satisfactory yield under both 6 and $12 \mathrm{dS} / \mathrm{m}$ saline condition. The yield of BD-891 was drastically reduced in $12 \mathrm{dS} / \mathrm{m}$ though it was second most top yield under 6 $\mathrm{dS} / \mathrm{m}$ salinity. BD-878 gave the worst performance in saline condition. Grain yield under saline condition reduced due to reduction of dry matter accumulation, shorter and lighter panicle. Hasan et al. (2015) stated that the spike per panicle, grains per spike and 1000-grain weight of wheat reduced significantly due to salinity. Studies conducted by Akram et al. (2000) and Kamkar et al. (2004) concluded that yield components of crop severely affected that leads to lower yield of crop in saline condition. However, reduction of photosynthesis, leaf longevity, pollen viability and stigma receptivity are responsible for lower yield under saline condition (Khatun and Flower, 1995; Morad et al., 2003).

\section{Relationship between grain yield and dry matter production}

The seed yield of foxtail millets demonstrated a significant linear association with dry matter production $\left(\mathrm{R}^{2}=0.37^{* *}\right)$ (Fig. 3), panicle length $\left(\mathrm{R}^{2}=0.36^{* *}\right)$ (Fig. 4), and panicle weight $\left(\mathrm{R}^{2}\right.$ $\left.=0.86^{* *}\right)$ (Fig. 5). 


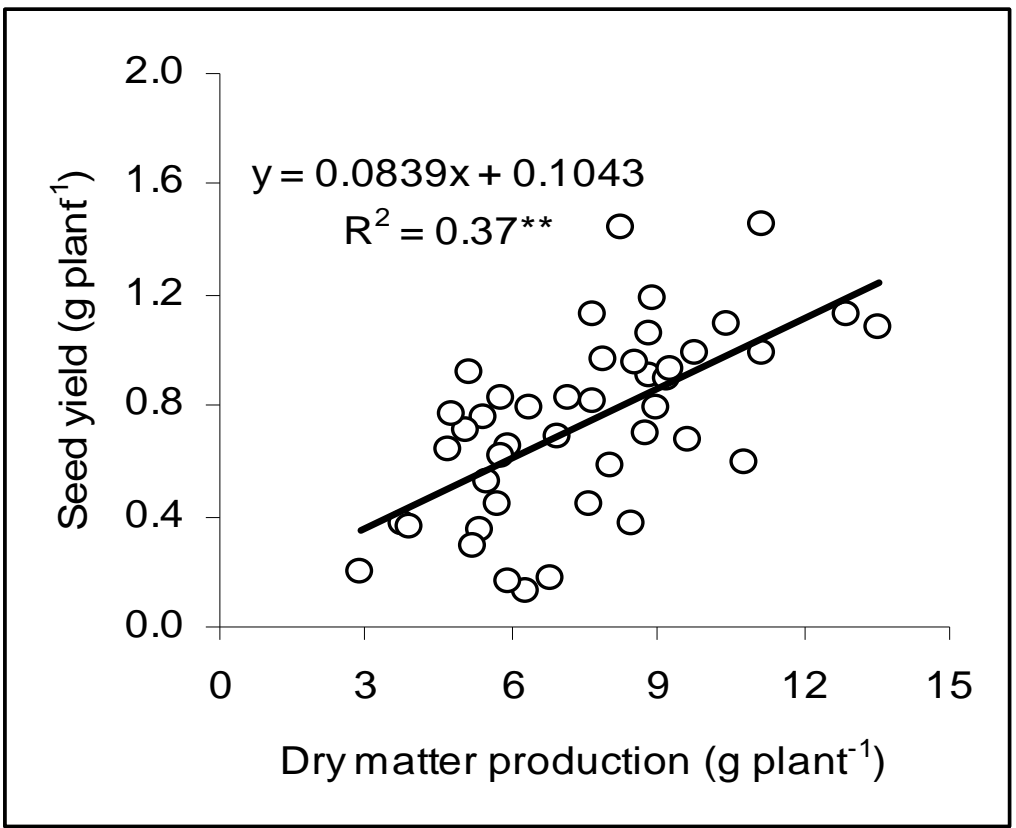

Fig. 3. Relationship between dry matter production and seed yield of foxtail millets $* *=$ Significant at $1 \%$ level of probability)

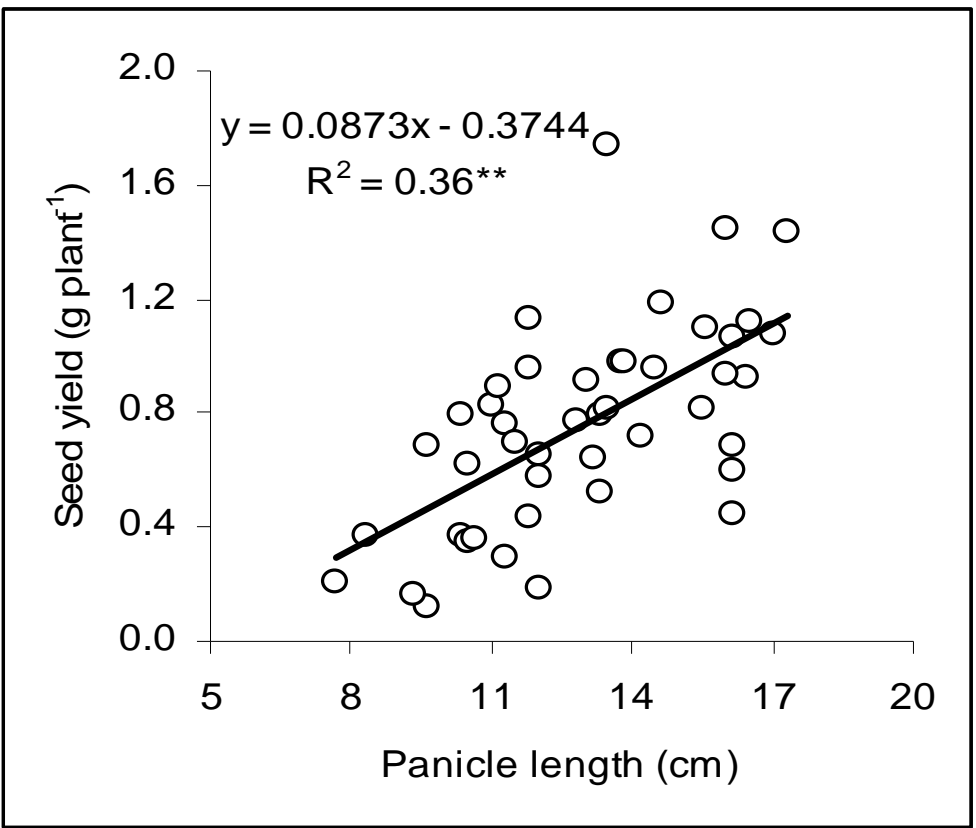

Fig. 4. Relationship between panicle length and seed yield of foxtail millets $(* *=$ Significant at $1 \%$ level of probability)

It indicated that the grain yield of foxtail millets increased with increasing dry matter, panicle length and panicle weight. The correlation coefficient ( $r$ ) indicated that salt tolerance index was related significantly with different yield attributes at $6 \mathrm{dS} / \mathrm{m}$ soil salinity (Table 3). 


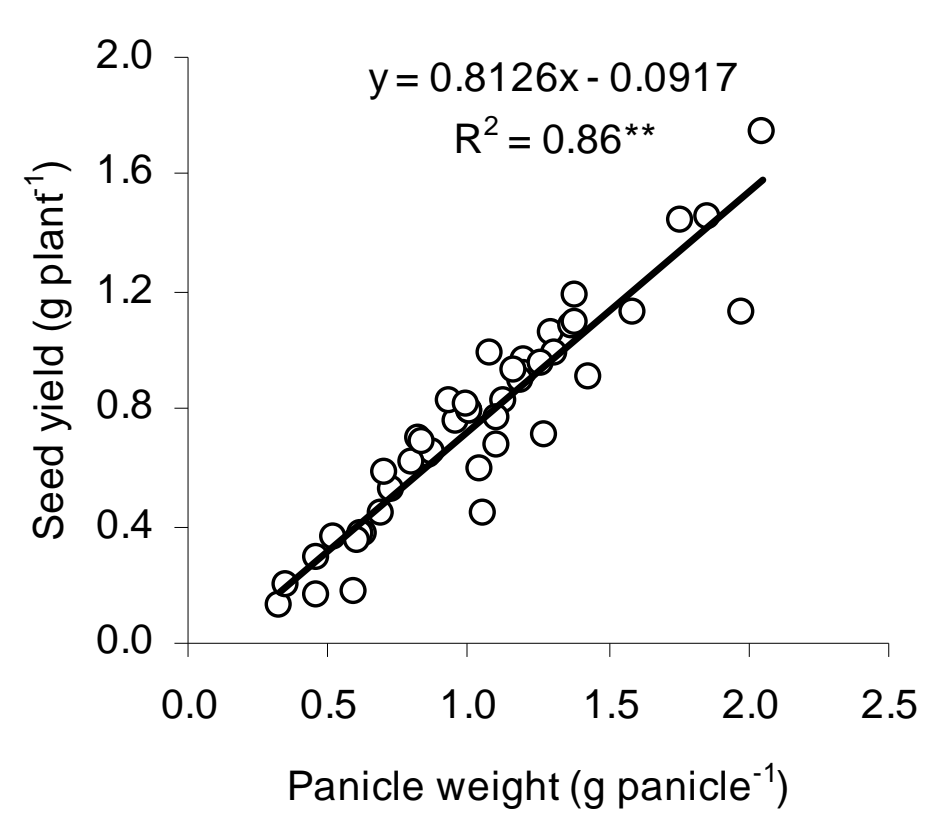

Fig. 5. Relationship between panicle weight and seed yield of foxtail millets $(* *=$ Significant at $1 \%$ level of probability)

Table 3. Correlation coefficient (r) between salt tolerance index and different yield attributes

\begin{tabular}{lll}
\hline Yield and yield attributes & $6 \mathrm{dS} / \mathrm{m}$ & $12 \mathrm{dS} / \mathrm{m}$ \\
\hline Panicle length & $0.40^{*}$ & $0.001^{\mathrm{NS}}$ \\
Panicle weight & $0.30^{*}$ & $0.07^{\mathrm{NS}}$ \\
Dry matter production & $0.70^{* *}$ & $0.09^{\mathrm{NS}}$ \\
Seed yield & $0.26^{*}$ & $0.12^{\mathrm{NS}}$ \\
\hline
\end{tabular}

* and ** indicate significant at 0.05 and 0.01 probability level, respectively. NS = not significant.

\section{Stress tolerance index (STI)and saline tolerance of foxtail millets genotypes}

Saline tolerance based on dry matter production and grain yield exhibited a wide range of variation among the tested foxtail millets genotypes (Figs. 6 and 7). In case of dry matter production, BD-897 demonstrated the highest stress tolerance index (STI) in $6 \mathrm{dS} / \mathrm{m}$ saline while BD-881 in $12 \mathrm{dS} / \mathrm{m}$ (Fig. 7). Based on grain yield, BD-897 as well as BD-891 showed the highest STI in $6 \mathrm{dS} / \mathrm{m}$ while BD-897 in $12 \mathrm{dS} / \mathrm{m}$ (Fig. 7). This indicated that salt stress lead to changes in growth, development, and productivity of sensitive millet genotypes and severe stress threaten the plant survival (Kafi, 2009). Zhi et al. (2004) screened 260 foxtail millet accessions using 1.0 and $1.5 \% \mathrm{NaCl}$ concentration, and concluded that this crop showed a wide range of variation $(0$ to $\sim 100 \%)$ in salt tolerance. 


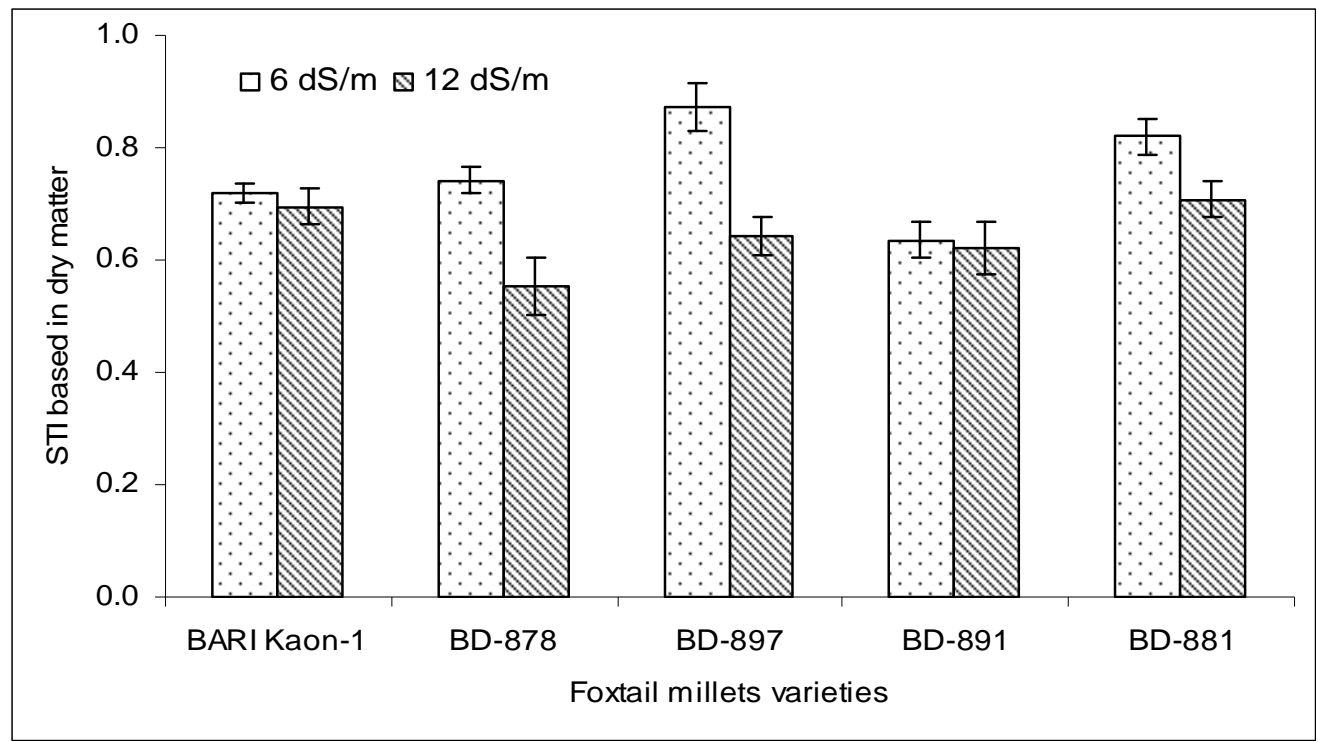

Fig. 6. Stress tolerance index (STI) of foxtail millet genotypes based on dry matter production

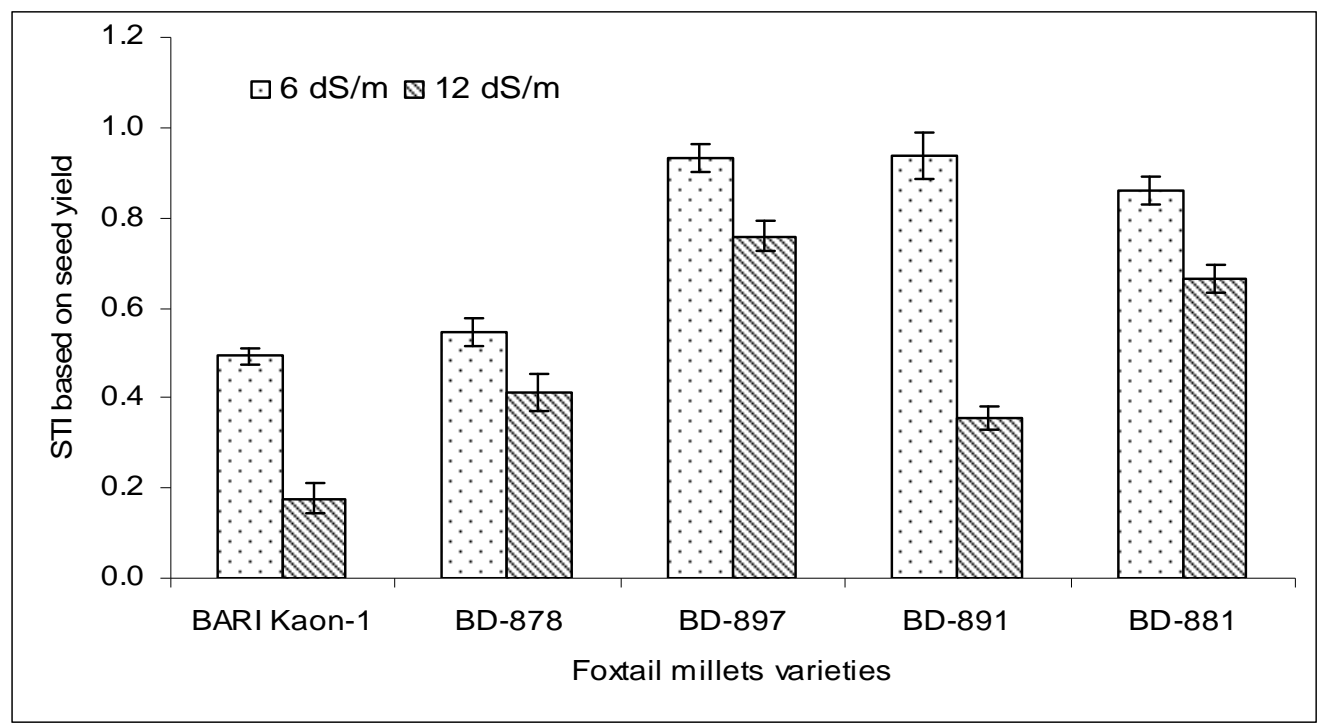

Fig. 7. Stress tolerance index (STI) of foxtail millet genotypes based on grain yield

\section{Conclusion}

The cropping intensity is low in saline affected areas of Bangladesh. In this study, it was found that foxtail millets genotypes BD-897 and BD-881 produced higher dry matter and grain yield under $6 \mathrm{dS} / \mathrm{m}$ salinity level. However, stress tolerance index of BD-897 and BD-881 were also higher. Therefore, it could be concluded that foxtail millets genotypes BD-897 and BD-881 may be cultivated in saline affected $(6 \mathrm{dS} / \mathrm{m})$ coastal areas of Bangladesh after satisfactory result from on farm trial at farmer's field at different salinity levels.

\section{References}


Akram, M., M. Hussain, S. Akhtar and E. Rasul. 2000. Impact of $\mathrm{NaCl}$ Salinity and yield components of some wheat accessions/varieties. Int. J. Agric. Biol. 1: 156-158.

Ashraf, M. Y., K. Akhtar, G. Sarwar and M. Ashraf. 2005. Role of rooting system in salt tolerance potential of different guar accessions. Agron. Sustain. Dev. 25: 243-249.

Austin, D. F. 2006. Fox-tail millets (Setaria: Poaceae) - Abandoned food in two hemispheres. Econ. Bot. 60 (2): 143-158.

Doust, A. N., E. A. Kellogg, K. M. Devos and J. L. Bentsen. 2009. Foxtail millet: a sequence-driven grass model system. Plant Physiol. 149: 137-141.

Evans, L. 2006. salinity tolerance in irrigated crops. NWS Department of primary Industries. Available online at http.//www.dip.nsw.au/arriculture/resources/soils/salinity/crops /tolerance-irrigated.

Fertilizer Recommendation Guide (FRG). 2012. Bangladesh Agricultural Research Council (BARC), Farmgate, Dhaka 1215, pp. 01-265.

Gomez, K. A., A. A. Gomez. 1984. Statistical procedure for agricultural research ( $2^{\text {nd }}$ ed.). John Willey and Sons, Singapore. pp. 28-192.

Hasan, A., H. R. Hafiz, N. Siddiqui, M. Khatun, R. Islam, M. A. A. Mamun. 2015. Evaluation of wheat genotypes for salt tolerance based on some physiological traits. J. Crop Sci. Biotech. 18 (5): $333-340$.

Kafi, M., G. H. Zamani and S. G. H. D. Ghoraishi. 2009. Relative salt tolerance of south Khorasan millets. DESERT 14: 63-70.

Kamkar, B., M. Kafi and A. N. Mahallati. 2004. Determination of the most sensitive development period of wheat (Triticum aestivum) to salt stress to optimize saline water utilization. 4th International Crop Science Congress, Iran Khaje-Hosseini M, Powell AA, Bingham IJ. 2003. The interaction between salinity stress and seed vigour during germination of soybean seeds. Seed Sci.Technol. 31: 715- 725.

Khatun, S. and T. J. Flowers. 1995. Effect of salinity on seed set of rice. Plant Cell Environ. 18: 6167.

Khan, M. A., M. U. Shirazi, M. A. Khan, S. M. Mujtaba, E. Islam, S. Mumtaz, A. Shereen, R. U. Ansari and M. Y. Ashraf. 2009. Role of proline, K/Na ratio and chlorophyll content in salt tolerance of wheat (Triticum aestivum L.). Pak. J. Bot. 41: 633-638.

Liu Z, G. Bai, D. Zhang, C. Znu, X. Xia, Z. Cheng and Z. Shi. 2011. Genetic diversity and population structure of elite foxtail millet (Setaria italic L. germplasm in China. Crop Sci. 51: $1655-1663$.

Liu, H., J. Zhang, K. B. Liu, N. Wu, Y. Li, K. Zhou, M. Ye, T. Zhang, H. Zhang, X. Yang, L. Shen, D. Xu and Q. Li. 2009. Earliest domestication of common millet (Panicum miliaceum) in East Asia extended to 10,000 years ago. Proceedings of the National Academy of Sciences of the United States of America. 106: 7367-7372.

Maas, E. V. 1985. Crop tolerance to saline sprinkling water. Plant Soil. 89: 273-284.

Morad, F., M. I. Abdelbagi, B. G. Glenn and A. E. James. 2003. Salinity tolerance of rice during reproductive development and association with tolerance at the seedling stage. Ind. J. Plant Physiol. Special Issue 8: 276-287.

Tanji, K. K. 1990. Nature and extent of agricultural salinity. In 'Agricultural Salinity Assessment and Management. (Eds KK Tanji) pp.1-18. American Society of Civil Engineers, New York.

Vetriventhan, M, H. D. Upadhyaya, C. R. Anand akumar, S. Senthilvel, H. K. Parzies, A. Bharathi, R. K. Varshney and C. L. L. Gowda. 2012. Assessing genetic diversity, allelic richness and 
genetic relationship among races in ICRISAT foxtail millet core collection. Plant Gene. Resour. 10: 214-223.

Zhen, Y., A. Jia, T. Ning, J. Xu, Z. Li and G. Jiang. 2008. Potassium nitrate application alleviates sodium chloride stress in winter wheat cultivars differing in salt tolerance. J. Plant Physiol. 165: $1455-1465$.

Zhi, H., Diao, X., Lu, P., Li, W., Akolova, Z. 2004. Methodology analysis on screening of salt tolerant genotypes from foxtail millet and other Setaria species. J. Hebei. Agr. Res. 8: 15-18. 